OPEN ACCESS

Edited by:

Dan H. Shugar.

University of Calgary, Canada

Reviewed by:

Ashim Sattar,

University of Dayton, United States

Andrew John Sole,

The University of Sheffield,

United Kingdom

*Correspondence:

Yongpeng Gao

22019000220@mail.ynu.edu.cn

Shiyin Liu

shiyin.liu@ynu.edu.cn

Specialty section:

This article was submitted to

Cryospheric Sciences,

a section of the journal

Frontiers in Earth Science

Received: 29 September 2020

Accepted: 19 January 2021

Published: 16 February 2021

Citation:

Gao Y, Liu S, Qi M, Xie F, Wu K and Zhu Y (2021) Glacier-Related Hazards

Along the International Karakoram

Highway: Status and

Future Perspectives.

Front. Earth Sci. 9:611501.

doi: 10.3389/feart.2021.611501

\section{Glacier-Related Hazards Along the International Karakoram Highway: Status and Future Perspectives}

\author{
Yongpeng Gao ${ }^{1,2 *}$, Shiyin Liu ${ }^{1,2,3 *}$, Miaomiao $Q i^{1,2}$, Fuming Xie ${ }^{1,2}$, Kunpeng $W u^{1,2}$ and \\ Yu Zhu ${ }^{1,2}$
}

${ }^{1}$ Yunnan Key Laboratory of International Rivers and Transboundary Eco-Security, Yunnan University, Kunming, China, ${ }^{2}$ Institute of International Rivers and Eco-security, Yunnan University, Yunnan, China, ${ }^{3}$ State Key Laboratory of Cryospheric Sciences, Northwest Institute of Eco-Environment and Resources, Chinese Academy of Sciences, Lanzhou, China

The China-Pakistan international Karakoram Highway passes through the core area of the "Karakoram Anomaly," whose glaciers have maintained or increased their mass during a period when most glaciers worldwide have receded. We synthesized the literature and used remote-sensing techniques to review the types, distribution, characteristics, causes and frequency of major glacial hazards along the Karakoram Highway. We found that the glacier-related hazards could be divided into direct and indirect hazards, including glacier surges, glacial lake outburst floods, and glacial floods, which are concentrated in East Pamir and the Hunza River Basin. In the past 100 years, hazards from glaciers surges and glacial floods only occurred once and twice, respectively, which appear suddenly, with the hazard-causing process being short-lived and occurring mainly in the summer. Glacial lake outburst floods mainly occur in the spring and summer in the Hunza River Basin. Among these, ice-dammed lakes have the highest frequency of flooding, their formation and outbursts being closely related to the sudden advancement of surge-type glaciers. Under the background of global climate warming, we speculate that the glacier surge cycle may shorten and the frequency of the formation and outbursts in the glacial lakes may increase. In the future, we should combine models and new field observations to simulate, and deepen our understanding of the physical mechanisms of different glacier-related hazards. In particular, on-site monitoring should be carried out, to include the evolution of glaciers subglacial hydrological systems, the thermal state at the base of the glaciers, and the opening and closing of drainage channels at the base of the ice dams.

Keywords: glacial floods, glacial lake outburst floods, glacier surges, China-Pakistan international karakoram highway (KKH), glacial hazards

\section{INTRODUCTION}

Any glacier or glacier-related feature or process that adversely affects human activities, directly or indirectly, can be regarded as a glacier hazard, which mainly includes glacial floods, glacial debris flows, glacier collapse and glacier surges, and avalanches (Reynolds, 1992; Richardson and Reynolds, 2000; Qin, 2016). Although a single glacier hazard event rarely involves as many casualties as a large earthquake or major volcanic eruption, the impact upon the safety of local or downstream people and infrastructure can be equally significant (Wu et al., 2019), especially in alpine regions where glaciers are widely distributed (Kotlyakov et al., 2004; Sun et al., 2014; Hu 

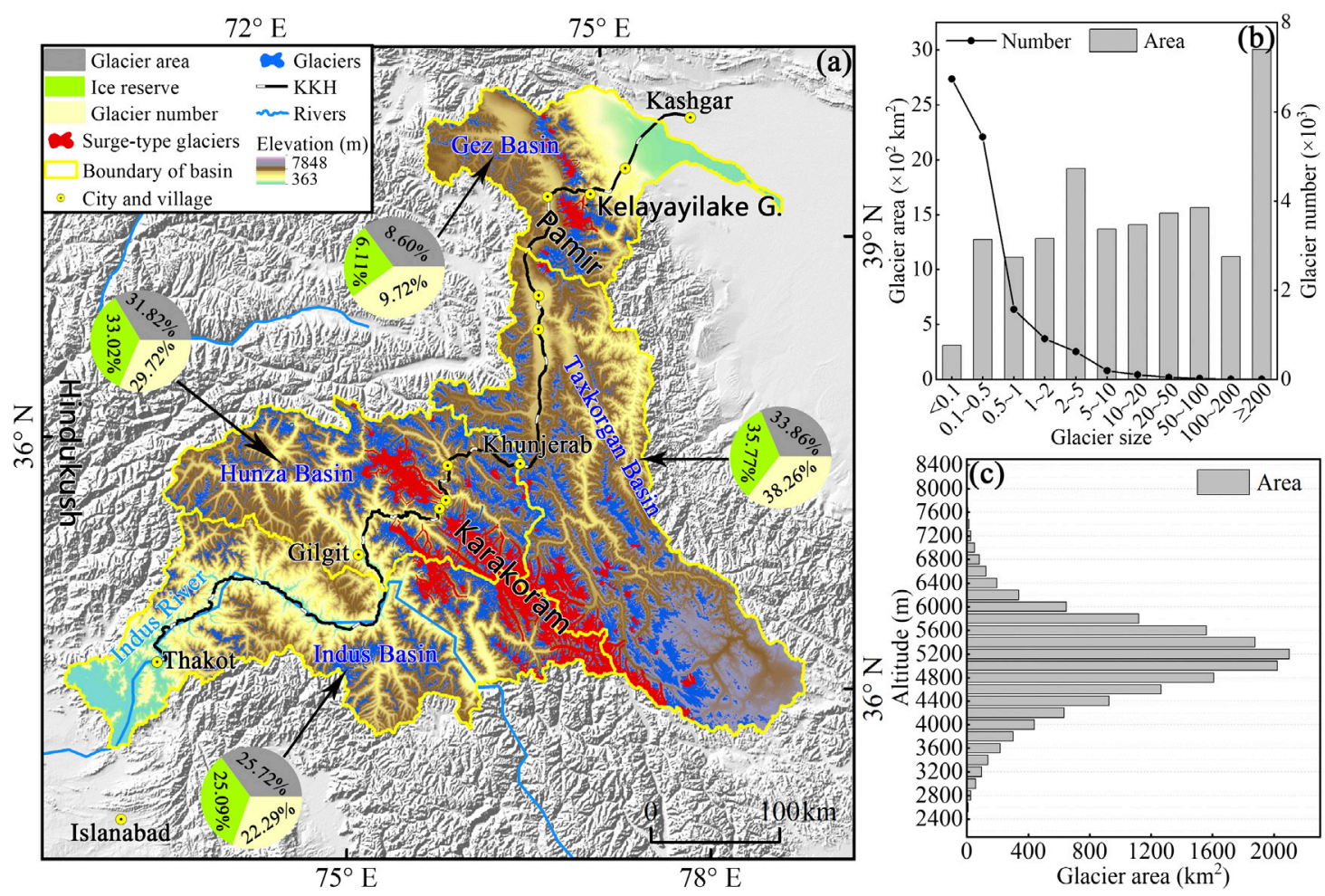

FIGURE 1 | (A) Spatial distribution of glaciers along the KKH. Percentages in the figure represent the percentage of glacier area, ice reserve and number in the corresponding total, respectively. (B) Number and area of glaciers in different area classes. (C) Glacial area distribution in different altitudes bands. The RGI 6.0 data were provided by the Global Land Ice Measurements from Space (RGI Consortium, 2017).

TABLE 1 | Historical records of glacier-related hazards in the $\mathrm{KKH}$.

\begin{tabular}{|c|c|c|c|c|c|}
\hline No & Date & Glacier name & Event & $\begin{array}{c}\text { Description of } \\
\text { hazard }\end{array}$ & References \\
\hline 1 & 1972 & Batura & GF & Destroyed subgrade and overturned an abutment & Shi (2003) \\
\hline 2 & 1973 & Batura & GF & Destroyed road subgrade, bridges and culverts & Shi and Zhang (1978) \\
\hline 3 & 1980 & Ghulkin & GF & Buried $400 \mathrm{~m}$ of road & Liao et al. (2013) \\
\hline 4 & 1974 & Balt bare & GLOF & Flooded friendship bridge and disrupted traffic & Cai et al. (1980) \\
\hline 5 & 2008 & Ghulkin & GLOF & Destroyed downstream pasu village and highway & Liao et al. (2013) \\
\hline 6 & 2008 & Pasu & GLOF & Disrupted traffic for two weeks & Zhu et al. (2014) \\
\hline 7 & 2019 & Shispare & GLOF & Formed an ice-dammed lake and destroyed the road & Bhambri et al. (2020) \\
\hline 8 & 2015 & Kelayayilake & GS & Destroyed pasture houses and threatened highways & Zhang et al. (2016) \\
\hline
\end{tabular}

et al., 2018; Kääb et al., 2018; Liu et al., 2019; Veh et al., 2019; Chen et al., 2020; Dubey and Goyal, 2020; Shugar et al., 2020).

The China-Pakistan international Karakoram Highway (KKH), with a total length of $1,224 \mathrm{~km}$, starts in Kashgar City, Xinjiang, North China, passes the Khunjerab Pass on the China-Pakistan border, and extends south to Thakot, a city in northern Pakistan (Figure 1A) (Zhu et al., 2014; Wang et al., 2019). The KKH traverses high mountainous regions, such as the Karakoram and Pamir, which are the most glaciated areas outside polar regions (Yao et al., 2019). Against the backdrop of global warming (Zhang and Gao, 2020), although the mass balance/volume/ extent of glaciers in the high mountains of Asia have decreased (Brun et al., 2017), a regional positive or near-equilibrium status has been identified in the Karakoram, Pamir and West Kunlun, a phenomenon termed the "Karakoram Anomaly" (Hewitt, 2005; Farinotti et al., 2020; Gao et al., 2020). Glaciers in this region have also undergone abnormal change, characterized by either stable or even advancing termini (Bhambri et al., 2017; Goerlich et al., 2020). The existing literature indicates that glacial hazards along the $\mathrm{KKH}$ mainly involve glacier surges, glacial lake outburst flood and glacial debris flows that are related to glacial floods (Table 1). However, the frequency, spatial and temporal distributions, and hazard-causing processes of the different glacier hazards remain unclear. This makes it difficult for us to improve our ability to prevent glacier hazards. Hence, to reduce the potential 
glacial risks along the $\mathrm{KKH}$, it is necessary to further review glacier-related hazards and to continue to study their processes and mechanisms.

Obtaining field data to strengthen our understanding of the formation of glacier hazards is difficult due to the hostile and remote environments that host the glaciers under examination. With the development of satellite and ground-based observation technology, and improvements in cognitive methods, remotelysensed data have successfully been employed to obtain information on difficult-to-access, glacier-related hazards and the characteristics of hazard-causing, surge-type glaciers, such as surge cycle recurrence intervals and surge phase durations (Bhambri et al., 2019; Bazai et al., 2020).

For this study, we obtained historical records of glacierrelated hazards along the $\mathrm{KKH}$ through a review of the literature. The aim was to better understand the frequency and characteristics of glacier hazards. Glaciers can advance rapidly during the active surge process. This can result in the damming of tributary valleys or ice-marginal alcoves. Along the $\mathrm{KKH}$, larger ice-dammed lakes form when glacier tongues block the lower sections of rivers and the drainage channels of adjacent glaciers. Historically, among the dominant glacierrelated hazards along the $\mathrm{KKH}$, ice-dammed lakes associated with glacier surges are the main cause of glacial lake outburst flood, which have caused significant damage to the KKH (Bazai et al., 2020; Rashid et al., 2020). To provide an improved understanding of glacier surges and ice dams, we explored annual velocity data and glacier surface elevations for the Khurdopin Glacier, which surged after 2012, forming an icedammed lake. Finally, we predicted a region along the KKH of potential high risk, where glacial hazards will likely occur frequently in the future. In addition, we have elaborated on some important knowledge gaps and have suggested some future necessary works.

\section{STATUS OF GLACIAL HAZARDS ALONG THE KKH}

\section{Distribution of Glaciers Along the KKH}

According to the Randolph Glacier Inventory (RGI) 6.0 statistics, a total of 15,961 glaciers exist in four basins that are crossed by the $\mathrm{KKH}$, and they cover an area of $15,903.88 \mathrm{~km}^{2}$ (Figure 1A). Figure 1B shows that the glaciers that are $>2.0 \mathrm{~km}^{2}$ in size occupy the largest area, while those $<1.0 \mathrm{~km}^{2}$ in size make up the greatest number of glaciers around the KKH. The number of glaciers reduces rapidly with an increase in area class (Figure 1B). The elevation of the glacierized area in the $\mathrm{KKH}$ has been analyzed at $200 \mathrm{~m}$ intervals, with the findings indicating that they are normally distributed across different altitude bands. The glacier area is concentrated between 3,600 and 6,600 $\mathrm{m}$ above sea level (96.77\%) (Figure 1C). Among the four basins, the greatest glacier areas, numbers and ice volume are in the Taxkorgan Basin (Figure 1A).

There are 187 surge-type glaciers along the $\mathrm{KKH}$ route, with those that threaten the normal operation of the highway, contained principally within the Gez and Hunza basins.
Historically, these glaciers have repeatedly triggered glacier hazards, damaging the $\mathrm{KKH}$ and disrupting traffic (Cai et al., 1980; Liao et al., 2013; Zhu et al., 2014; Bhambri et al., 2019; Bazai et al., 2020; Rashid et al., 2020).

\section{Type, Distribution, Processes and Characteristics of Glacier-Related Hazards Glacier Surges (GSs)}

GSs exhibit cyclic behavior between long periods (10-100 s of years) of quiescence and shorter periods (1-10 years) of activity, during which ice surface velocities increase by up to three orders of magnitude (e.g., Meier and Post, 1969; Clarke et al., 1984; Jiskoot et al., 1998). During surges, a significant volume of the entire ice mass is rapidly transferred from the reservoir to the receiving area, often leading to dramatic changes in glacier surface height and an advance of the glacier terminus (Raymond, 1987; Fowler et al., 2001; Sevestre and Benn, 2015; Lv et al., 2019). Hazard-causing GSs have only occurred once along the KKH. In May 2015, herdsmen residing near Kelayayilake Glacier (Figure 1A), located in East Pamir, stated that fast-moving glacier ice had destroyed pasture and killed many of their livestock (Shangguan et al., 2016). The surging of the Kelayayilake Glacier began in February 2015 (Zhang et al., 2016). The surge front propagated down-glacier from upstream to downstream, between 28 February, 2015 and 29 April, 2015. Around April 13, 2015, the glacier began to move significantly, its surface speed accelerating and reaching its fastest rate on May $8-15,2015$ (Yao et al., 2019). The average rate of the west branch surge was $5.06 \pm 0.42 \mathrm{~m} \mathrm{~d}^{-1}$, with its maximum visible rate reaching $20.40 \pm 0.42 \mathrm{~m} \mathrm{~d}^{-1}$ in the central part of the west branch. The glacier's movement subsequently decreased significantly, with the average rate of the west branch dropping to $0.63 \pm 0.05 \mathrm{~m} \mathrm{~d}^{-1}$ during the period May 15 to July 11, 2015 (Zhang et al., 2016). In addition, the average elevation of the glacier receiving area increased by $20-40 \mathrm{~m}$, with $2.7-3.6 \times 10^{8} \mathrm{~m}^{3}$ of ice being transferred from the glacier reservoir area during the active phase, causing the $3.5-\mathrm{km}-\mathrm{long}$ glacier tongue to remain connected to the main glacier but accelerate with the front advancing rapidly, eventually submerging the surrounding grassland and some houses (Yao et al., 2019).

Therefore, we can summarize the characteristics of hazardcausing GSs from the process of surging in the Kelayayilake Glacier. GS hazards are generally caused by the advancement of the glacier terminus. The timing of the hazards depends on how fast the glacier accelerates to its peak velocity. Compared with GDFs and GLOFs, GS hazards are typically less destructive and affect a smaller area.

\section{Glacial Lake Outburst Floods (GLOFs)}

We compiled an inventory of historical GLOFs that have occurred along the $\mathrm{KKH}$ from the published scientific literature from 1873 to 2020 (Hayden, 1907; Mason, 1930; Hewitt, 1982; Goudie et al., 1984; Kreutzmann, 1994; Iturrizaga, 1997; Hewitt, 2006; Hewitt and Liu, 2010; Hewitt, 2014; Harrison et al., 2018; Bhambri et al., 2019; Bazai et al., 2020; 


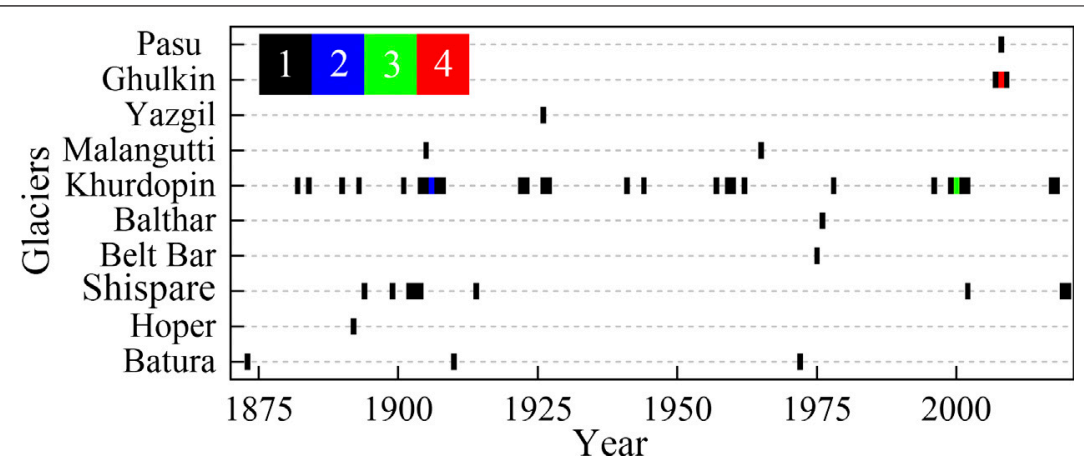

FIGURE 2 | Frequency of GLOFs along the KKH since 1873. The colored boxes represents the number of GLOFs per year.



FIGURE 3 | Spatial distribution of GLOFs along the KKH. Background: Landsat Operational Land Imager (OLI) image (Bands 6, 5, and 4), mosaicked from LC08_L1TP_149035_20200825_20200905_01_T1, LC08_L1TP_149034_20190924_20191017_01_T1, LC08_L1TP_150034_20180912_20180927_01_T1 and LC08_L1TP_150035_20150819_20170406_01_T1.

Saifullah et al., 2020). We documented 56 GLOF events (Figure 2), which were mainly distributed in the Hunza Basin. Among them, 45 GLOF events (80\%) were associated with ice dams attributed to six glaciers (Ghulkin, Malangutti, Yazgil, Khurdopin, Shispare and Batura) in two major valleys (Shimshal and Hunza) of the Hunza Basin (Figure 3). Figure 2 shows plots of the incidence of GLOFs associated with different glaciers in the Hunza Basin. The majority (57\%) of the documented GLOFs occurred between 1873 and 1970, with $43 \%$ happening since 1970 . GLOF events were most frequent in the years 1890-1930 and 1996-2020. In terms of the distribution of GLOFs in the Hunza Basin, 39.29\% were in the Hunza Valley, $60.71 \%$ in the Shimshal Valley. The Shispare (Hunza Valley) and Khurdopin (Shimshal Valley) Glaciers were the most active in terms of glacier dam formation and GLOFs, which together accounted for $71.43 \%$ of the GLOF events. Both the terminal of the Shispare and Khurdopin Glaciers are located in the upper reaches of valleys (Figure 3), where relatively narrow river channels are easier to block, and river discharge is low, with the ratios of the ice overburden pressure to the subglacial water pressure allowing frequent resealing of drainage conduits in the ice body and lake re-formation. Although most of the other glaciers account for only a low percentage of total GLOFs, they cannot be ignored; for example, four GLOFs were associated with Ghulkin Glacier in 2008 (Liao et al., 2013).

Table 2 distills the characteristics of the major GLOF events in the Hunza Basin. We found that outburst floods occurred most often in the late spring (April and May) and summer (June, July and August), and that the type of GLOF event differed among the glaciers (related to ice-dammed, supra-glacial or moraine- 
TABLE 2 | Historical records of major GLOF events in the Hunza Basin.

\begin{tabular}{|c|c|c|c|c|c|c|c|}
\hline Year & Event date & Glacier & Type of glacier lake & Valley & Peak volume $\left(10^{6} \mathrm{~m}^{3}\right)$ & Peak discharge $\left(10^{4} \mathrm{~m}^{3} / \mathrm{s}\right)$ & Trigger factors \\
\hline 1905 & 2 August & Khurdopin & Ice-dammed lake & Shimshal & - & - & High temperature \\
\hline 1906 & 11 August & Khurdopin & Ice-dammed lake & Shimshal & - & - & High temperature \\
\hline 2000 & 11 June & Khurdopin & Ice-dammed lake & Shimshal & 186 & 19.80 & High temperature \\
\hline 2001 & 4 July & Khurdopin & Ice-dammed lake & Shimshal & 10 & 1.01 & High temperature \\
\hline 2002 & 15 July & Khurdopin & Ice-dammed lake & Shimshal & 19 & 1.95 & High temperature \\
\hline 2007 & 5 April & Ghulkin & Supra-glacial lake & Hunza & - & - & Western disturbance \\
\hline 2008 & 6 January & Pasu & Moraine-dammed lake & Hunza & - & - & Western disturbance \\
\hline 2008 & 2 April & Ghulkin & Supra-glacial lake & Hunza & - & - & Western disturbance \\
\hline 2008 & 22 May & Ghulkin & Supra-glacial lake & Hunza & - & - & Persistent rainfall \\
\hline 2008 & 24 May & Ghulkin & Supra-glacial lake & Hunza & - & - & Persistent rainfall \\
\hline 2008 & 14/15 June & Ghulkin & Supra-glacial lake & Hunza & - & - & High temperature \\
\hline 2009 & 26 March & Ghulkin & Supra-glacial lake & Hunza & - & - & Western disturbance \\
\hline 2017 & 24 July & Khurdopin & Ice-dammed lake & Shimshal & 5 & 0.5 & High temperature \\
\hline 2018 & 9 February & Khurdopin & Ice-dammed lake & Shimshal & 9 & 0.91 & High temperature \\
\hline 2019 & 30 May & Shispare & Ice-dammed lake & Hunza & 9.97 & 1.01 & High temperature \\
\hline 2020 & 7 April & Shispare & Ice-dammed lake & Hunza & 12.45 & 1.27 & High temperature \\
\hline
\end{tabular}



dammed lakes). The factors triggering outburst floods include high temperatures leading to enhanced glacier ablation and runoff, persistent rainfall, and western disturbance (Dimri, 2004; Roy and Bhowmik, 2005). Based on the available remote-sensing data, peak lake volumes were attained before flooding in the Khurdopin and Shispare Glaciers, suggesting that water volume is of great importance, and that there is an influence from topographical and sub-glacial drainage conduits (Bazai et al., 2020). We used empirical formulae (Huggel et al., 2002) to calculate the peak discharge of GLOFs, which were found to lie between $0.5 \times 10^{4}$ and $19.80 \times 10^{4} \mathrm{~m}^{3} / \mathrm{s}$. In addition, GLOFs have a large hazard-causing range, often destroying roads, farmland and villages of Hunza valley.

Most GLOF events in the Hunza Basin are related to the advance/disturbance of glacier termini. Below, we outline the relationship between GSs and glacier lake formation, and the process that causes GLOFs, using examples from a surge-type
glacier--Khurdopin. According to reports in the literature (Bazai et al., 2020), Khurdopin Lake caused 31 GLOF events between 1882 and 2020. The characteristics of the surface velocities of the glacier were monitored, from 2016 to 2020, using an application for the cross-correlation feature-tracking of Landsat $8 \mathrm{OLI}$ images and Co-registration of Optically Sensed Images and Correlation methodology (Figure 4A) (Leprince et al., 2007). We obtained the changes in surface elevation from a digital elevation model that was extracted by the MMASTER tool (Girod et al., 2017), using ASTER-L1A data (2015/10/07 and 2020/08/17) (Figure 4B). One recent (2016-2017) GS caused three GLOFs (9.68\%), and remotesensing data successfully revealed the process behind the GS and ice lake formation.

The surging of the Khurdopin Glacier begins in the winter and accelerates in the early spring, when glacier-surface meltwater is added to the sub-glacial drainage system (Figure 4A). Peak velocity is reached when sub-glacial water reduces the effective 

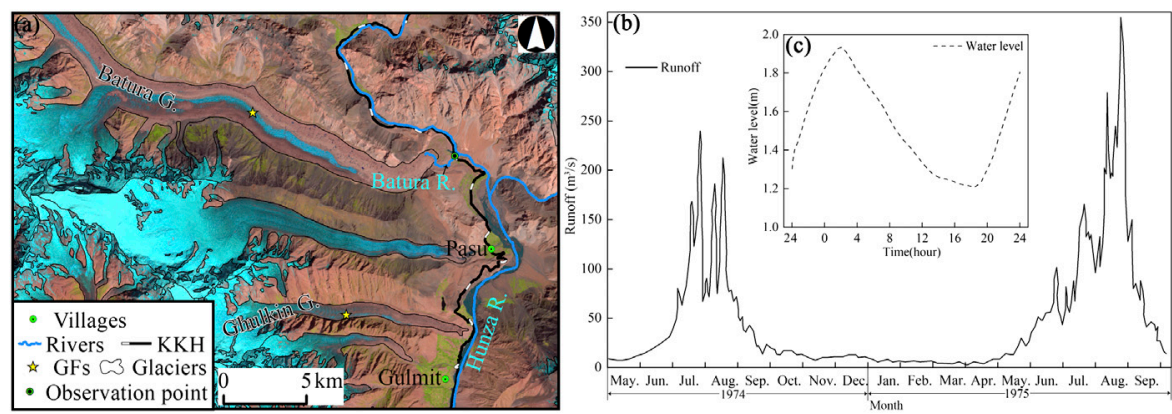

FIGURE 5 | (A) Spatial distribution of GFs along the KKH. Background: Landsat OLI image (Bands 6, 5 and 4) from LC08_L1TP_149035_20200825_20200905_01_T1. (B) Discharge process curve for the Batura River from May 1974 to September 1975. (C) Change in daily water level of the Batura River on August 18, 1975. Data from the Batura Glacier Investigation Group (1979).

pressure at the glacier bed during the spring and summer (Figure 4A). During an active surge phase, mass is transferred from the reservoir zone to the receiving zone, facilitating the extension and thickening of high-mass barriers at the glacier terminus that efficiently block the drainage channels of the adjacent glacier, forming ice-dammed lakes (Figure 4B). Glacier velocity reduces toward the end of summer, the resulting lake is breached during periods of high atmospheric temperatures when glacier ablation and runoff are enhanced (Table 2). Following GLOFs, the lakes are usually re-sealed in the winter because the lake water depth is insufficient to partially float the ice dam.

\section{Glacial Floods (GFs)}

As opposed to GLOFs, GFs may be released directly from a glacier, either sub-, en- or supra-glacially (Richardson and Reynolds, 2000). There are only three records of GFs occurring along the $\mathrm{KKH}$ in history, these being caused by the Batura and Ghulkin Glaciers in the Hunza Basin (Figure 5A). Among them, the GFs of Batura Glacier occurred in the summers of 1972 and 1973 because of high temperatures. The GF from Ghulkin Glacier triggered a GDF, leading to the burial of a 400m-stretch of highway in August 1980 (Jones et al., 1983).

Figures 5B,C shows the discharge process of the Batura River, from May 1974 to September 1975, and the change in daily water level in the Batura River on August 18, 1975, respectively. According to field measurement data provided by the Batura Glacier Investigation Group (1979), the average flow of the Batura River in summer, from June to August, was $89.4 \mathrm{~m}^{3} \mathrm{~s}^{-1}$ in 1974 and $125.0 \mathrm{~m}^{3} \mathrm{~s}^{-1}$ in 1975 . The maximum instantaneous flow rate was $307 \mathrm{~m}^{3} \mathrm{~s}^{-1}$ (July 23) in 1974 and $417 \mathrm{~m}^{3} \mathrm{~s}^{-1}$ (August 18) in 1975 , with the maximum flow velocity being $7-8 \mathrm{~m} \mathrm{~s}^{-1}$.

We can thus summarize the characteristics of abovementioned GFs. The GFs were triggered by glacier melt resulting from high temperatures, and mainly occurred in summer along the $\mathrm{KKH}$. Their hazard-causing frequency is low. In addition, the Batura and Ghulkin Glaciers are $<300 \mathrm{~m}$ from the highway (Figure 5A), and so the hazard-causing intensity of GFs is greater than from GSs. The peak discharge of a GF is related to the size of the glacier, but these data are often difficult to obtain due to the suddenness of GFs.

\section{DISCUSSION}

\section{Trigger Mechanisms of Glacier-Related Hazards \\ Trigger Mechanisms of GSs}

Glacial hazards along the KKH mainly stem from GLOFs that are related to GSs (Bazai et al., 2020). Current academic thinking interprets the GSs mechanism in terms of hydrological (Alaskantype surge-type glacier) or thermal (Svalbard-type surge-type glacier) mechanisms (Quincey et al., 2015). The former camp believes that the drainage system at the base of the glacier changes from channelized to distributed, which triggers the GSs. Hydrologically driven surges initiate in the early winter as the summer conduits begin to shut down and water pressure increases in a more inefficient distributed drainage system. Such surges typically end with a release of subglacial water as the distributed system reverts back to a more efficient channelized system once the flux of water into the distributed system exceeds a critical stability threshold. Thus surge cessation often occurs during the summer, its active phase usually lasting 1-3 years (Kamb et al., 1985; Kamb, 1987; Raymond, 1987; Lingle and Fatland, 2003; Burgess et al., 2012). The hydrology trigger is usually associated with surges at temperate glaciers. The latter camp posits that a change from frozen to unfrozen conditions at the bed promote increased sediment deformation and porosity and a positive feedback between pore water pressure, deformation, and basal flow ensues. In this scenario, the GSs can be started in any season, while its active phase generally lasts for >3 years (Clarke et al., 1977; Clarke, 1984; Murray et al., 2003; Frappé and Clarke, 2007). The thermal trigger is usually associated with polythermal glacier surges. In addition, some scholars (Sevestre and Benn, 2015; Benn et al., 2019; Benn et al., 2019) have also presented a general theory for GSs that includes both temperate and polythermal GSs, based on coupled mass and enthalpy budgets. They posited that enthalpy is obtained at the glacier bed from geothermal heating plus frictional heating, caused by ice flow and enthalpy losses occurring by conduction and the loss of meltwater from the system. Mass and enthalpy budgets must simultaneously balance if a glacier is to maintain a steady flow because enthalpy directly impacts flow speeds. If not, glaciers undergo out-of-phase mass and enthalpy 
cycles, manifested as quiescent and surge phases. Most of the surging of glaciers along the $\mathrm{KKH}$ in recent years occurred in the initial stages of the period of glacial melting (Bazai et al., 2020). For example, the Hispar Glacier started to surge in May 2013 (Rashid et al., 2018), while the west branch of the Kelayayailake Glacier began to surge and accelerate in April 2015 (Yao et al., 2019). Also, the Khurdopin Glacier showed a peak surge speed in May 2017 (Steiner et al., 2018), while the Shispare Glacier's surface movement gradually increased from April to May 2017 (Bhambri et al., 2020). The acceleration and deceleration of glaciers mainly depends on the hydraulic efficiency at the base of the ice during the surging process, which involves a hydrological mechanism (Raymond, 1987). Some of this water is generated by internal processes, such as friction, pressure and geothermal heat, but most of it is surface-derived meltwater that reaches the base of the glacier through crevasses and moulins (Copland et al., 2011; Yasuda and Furuya, 2015). As the temperature rises in spring, snow on the surface of the glacier gradually melts, the impact of liquid precipitation, and the development of fissures on the surface of the glacier in this area allows the surface meltwater to penetrate to the base of the glacier, which may promote the sliding of the glacier (Iken, 1981; Iken and Bindschadler, 1986). It is worth noting, however, that the GSs start time along the KKH is different from the start time of Alaskan-type surge-type glaciers (Bhambri et al., 2020). At present, there is no strong, measured evidence to explain why these start times are different. Future field observations should focus on finding evidence to explain these processes and differences, especially in terms of the evolution of the drainage systems of surge-type glaciers in the melting season.

Glaciers are a product of climate and topography, and are very sensitive to climate change (Yao et al., 2019). Recent studies have found that, when westerly atmospheric jets are located south of the Karakoram Mountains in the winter, mid-latitude cyclones (or westerlies) control the weather in the region, and their weather fronts interact with the extreme topography to produce copious amounts of mountain precipitation (Farinotti et al., 2020). From 1979 to 2010, the intensity and frequency of this westerly induced precipitation increased, which may have caused a slight increase in snowfall in winter (Norris et al., 2019). This is consistent with the near-stable state of the glacier mass balance in the areas along the KKH from 2000 to 2014 (Bolch et al., 2017; Lin et al., 2017). The continuous accumulation of ice in the glacier accumulation area has caused the glaciers to thicken and their shear stress to increase, leading to an increase in the creep rate of the ice and heat generation, ultimately promoting a positive feedback between the rapid movement of the ice body and the strain heating (Clarke et al., 1984). Eventually, the base of a glacier will reach the pressure melting point and produce meltwater. The ice body itself, and the frozen soil downstream of the glacier, hinder the progress of this glacial meltwater, and lead to an increase in basal water pressure causing the ice body to slide rapidly (Clarke, 1977). When the drainage system at the base of the glacier becomes unblocked, the GS ends. Typical cases of this process include the west branch of the Kelayayilake Glacier's ablation zone, which increased by an average of $0.45 \pm 0.70 \mathrm{~m}$ during its surge, and where there was a clear process of glacial material migration (Zhang et al., 2016). In the Shispare Glacier, the terminus thickened by nearly $200 \mathrm{~m}$ during its surge (Bhambri et al., 2020). Steiner et al. (2018) pointed out that the ice tongue of the Khurdopin Glacier was thickened by 50-160 m, causing the ice at the base of the glacier to deform and gradually warm-up, and the basal substrate to slide, leading to a peak in the speed of the GS. This is a typical thermal mechanism, similar to the process in surge-type glaciers of the Svalbard-type.

We can thus infer that the GS trigger mechanism along the $\mathrm{KKH}$ is the result of multiple factors because a single mechanism cannot explain the process. Quincey et al. (2015) also determined that glacier movement in this area showed strong spatial heterogeneity, based on data from nine glaciers in the Karakoram Mountains, and that there was no single trigger mechanism for these glaciers. GS triggering mechanisms are not only connected to a glacier's properties, but are also closely related to external factors, such as increased short-term precipitation, ice bed lithology, avalanches and earthquakes. Gilbert et al. (2018) pointed out that dual surge-like collapses in the Aru region of Tibet in 2016 would have been driven by a failing basal substrate linked to increasing pore-water pressure in the sub-glacial drainage system, in response to increases in surface melting and rainfall during the 5-6 years preceding the collapse dates.

At present, monitoring the glaciers along the $\mathrm{KKH}$ through remote sensing alone may limit our further understanding of their surge mechanisms (Farinotti et al., 2020). In the future, as the global climate continues to warm, the attributes of the glaciers themselves will change (including decreased ice albedo, increased ice temperatures, increased ice fragmentation and abnormal flow speeds) (Ding et al., 2020). This will make it more difficult for us to understand the surge mechanisms of surge-type glaciers. Therefore, effective fieldwork will be needed, especially observations of glacial bed lithology, basal deformation rates, in-ice drainage systems, etc. (Hewitt, 2005; Quincey et al., 2011; Bhambri et al., 2017). These will greatly improve our ability to respond to hazards resulting from GSs.

\section{Trigger Mechanisms of GLOFs}

The advancing or surging of glaciers in Hunza Basin often blocks the main valley, causing water storage in ice-dammed lakes (Yao et al., 2017). These ice-dammed lakes drain by overtopping or by flow through sub-glacial tunnels, the latter mechanism being the more common of the two (Ng and Björnsson, 2003; Björnsson, 2017). Initial outflow via a sub-glacial tunnel may be triggered by the flotation of part of the ice dam that is in contact with the lake, although flotation does not appear to be a requirement for the initiation of drainage (Haeberli, 1983). As the water begins to flow along a sub-glacial channel, the channel walls enlarge by both thermal and mechanical erosion. The channels can, however, narrow or close during or after the flood via ice deformation caused by glacier flow, especially if the ice is thick ( $\mathrm{Ng}$ and Liu, 2009). The outburst floods of the ice-dammed lakes of the Shispare and Khurdopin Glaciers were discharged from outlets at the glacier termini. The opening of drainage channels under ice dams is closely related to factors such as basal water and the 




FIGURE 6 | Repeat cycles of surging in KKH glaciers. Surge duration indicated by the length of the thick black lines.

configuration or hydraulic efficiency of the subglacial drainage system and whether there is a river network under the ice. Whether the drainage of the Shispare and Khurdopin icedammed lakes is related to this requires evidence from further field investigation. It is puzzling that the most recent GS of the Shispare Glacier did not stop when the ice-dammed lake at the end of the glacier drained. Such GLOFs are not well understood, but may involve the sudden rupturing of pressurized, water-filled, englacial cavities that fracture the base of the glacier through high hydrostatic pressures or rapidly changing inflow. There is only one moraine-dammed lake along the $\mathrm{KKH}--$ the glacial lake at the end of the Pasu Glacier. Its outburst was mainly due to overtopping on January 6,2008 , caused by an ice avalanche entering the lake (Zhu et al., 2014).

\section{Future Changes in Risks From Different Glacier-Related Hazards}

Overall, against a backdrop of continuous global warming in the future (Forsythe et al., 2017), the frequency of glacier-related hazards along the KKH will show an increasing trend (Harrison et al., 2018; Bazai et al., 2020). Figure 6 illustrates the frequency of surge-type glaciers along the KKH over the past 150 years. It can be seen that, since the construction and opening of the KKH, GSs have been triggered 21 times. In terms of interdecadal change, surge-type glaciers along the $\mathrm{KKH}$ were relatively active before the 1930s, but became relatively stable from the 1930s to 1960s; however, this may be related to a lack of data from this period. After the 1960s, the number of GSs also gradually increased. In the last decade in particular, with enhanced global warming, there have been as many as seven GSs in the region, accounting for 15\% of the total number of GSs since the construction of the KKH. Therefore, it is likely that the surge-type glaciers along the highway will become more active in the future, and so the probability of hazard will also increase.

Where two or more active phases can be determined for a given glacier, there is a basis for establishing recurrence intervals. If consistent between events, these could help predict the timing of future surges (Bhambri et al., 2017). We identified two or more surges related to 10 glaciers by summarizing the literature (Figure 6) (Bhambri et al., 2017; Bazai et al., 2020). The most extensive records of repeat cycles are for the Bualtar, Ghulkin, Balt Bare, Hoper, Batura, Muchuhar, Shispare, Yagjil, Malangutti, and Khurdopin Glaciers (Figure 6). The data suggest that the Khurdopin Glacier in the Shimshal Valley is the most active surge-type glacier in two centuries. Seven surge events of the Khurdopin Glacier suggest a cyclicity or recurring instability threshold of 20 years. Therefore, we speculate that the Khurdopin Glacier may surge again in the next 20 years, and may also advance due to extreme weather events. Although the Malangutti Glacier has an unstable cycle, its surge recurrence intervals are shortening. Four surge events of the Yagjil Glacier have been identified since the 1990s, with a surge cycle of approximately 6 years. The Shispare and Muchuhar Glaciers surged 10 times in 1894-2019. The 10 recurrence intervals cluster between 3 and 49 years, with the most recent two being 24 and 12 years apart. The Bualtar Glacier is unusual in having pairs of closely-timed active surges, in 1922-1923, 1929-1930, and 1987 and 1990--a curious case of alternating short and long quiescent phases. The reason for this behavior is unclear, and presents another glacier-determined rhythm that complicates the tracking of their relation to climate. Surge recurrence intervals for the remaining glaciers are more than 30 years. The intervals between the two surges of the Ghulkin and Batura Glaciers are 41 and 40 years, respectively; this may be shortened by climate change in the future (Ding et al., 2020; Farinotti et al., 2020). The Balt Bare Glacier surged in both 1976-1977 and 2006-2012. Although this surge cycle was close to 30 years, the surge timing was after the KKH was completed. In 1974, the glacial lake at the terminus of the Balt Bare Glacier burst, causing a mudslide that washed away the road (Cai et al., 1980). Therefore, the Balt Bare Glacier poses a significant threat to the safety of roads and downstream villages.

Glacier ice velocities can reflect the flow state of glaciers, and may be able to be used to predict the risk of glacier-related hazards in the future. Wang et al. (2019) obtained the ice velocities of the glaciers along the $\mathrm{KKH}$ from January 2016 to May 2017, based on Sentinel-1A data. They found that the ice velocities of the glaciers along the northern part of the highway were slower and more stable during the study period, and that the ice velocities of the glacier tongues near the highway were all within $0.15 \mathrm{~m} / \mathrm{d}$. The glaciers around the central part of the $\mathrm{KKH}$ are scattered and relatively small in area, and so are less likely to pose a threat to the lives and productivity of the residents over the short term. The glaciers along the southern part of the $\mathrm{KKH}$, however, are large in area and densely distributed. Most of these are surge-type glaciers, and their velocities are relatively high. We used ITS_LIVE data (Gardner et al., 2019) to explore the average ice velocities of the surge-type glaciers along the KKH from 1985 to 2018. This revealed that the average ice velocities of glaciers in the northern part of the highway have been low for 33 years, suggesting a relatively low level of threat to highway safety, but some large glaciers may affect downstream areas in the future, such as the Kelayayilake Glacier (Figure 7B). The Hunza Basin in the southern part of the $\mathrm{KKH}$ is an area in which surge-type 



FIGURE 7 | Mean ice velocities along the KKH from 1985 to 2018. Ice velocity data obtained from ITS LIVE https://nsidc.org/apps/itslive/. (A) Hunza River Basin. (B) Northeast Pamir (C-E) Three areas prone to GLOFs in the future. (F) Evolution of the area, peak discharge, mean depth and water volume in the ice-dammed lake of the Khurdopin Glacier. Remote-sensing images downloaded from https://glovis.usgs.gov/. The result of Rashid et al. (2020) was referenced about the floodprone areas.

glaciers are concentrated. The average ice velocities of these glaciers have been relatively high in the past 33 years (Figure 7A), and so this presents the potential for a high risk of hazards. Figure 8 shows the change in annual velocity of surge- type glaciers in the Hunza Basin in 2013-2020. After the Khurdopin Glacier stopped surging, the velocity of the glacier terminus slowed (Figure 8H). We consider that the possibility of ice-dammed lake formation here is low in 2021, so the risk of a 


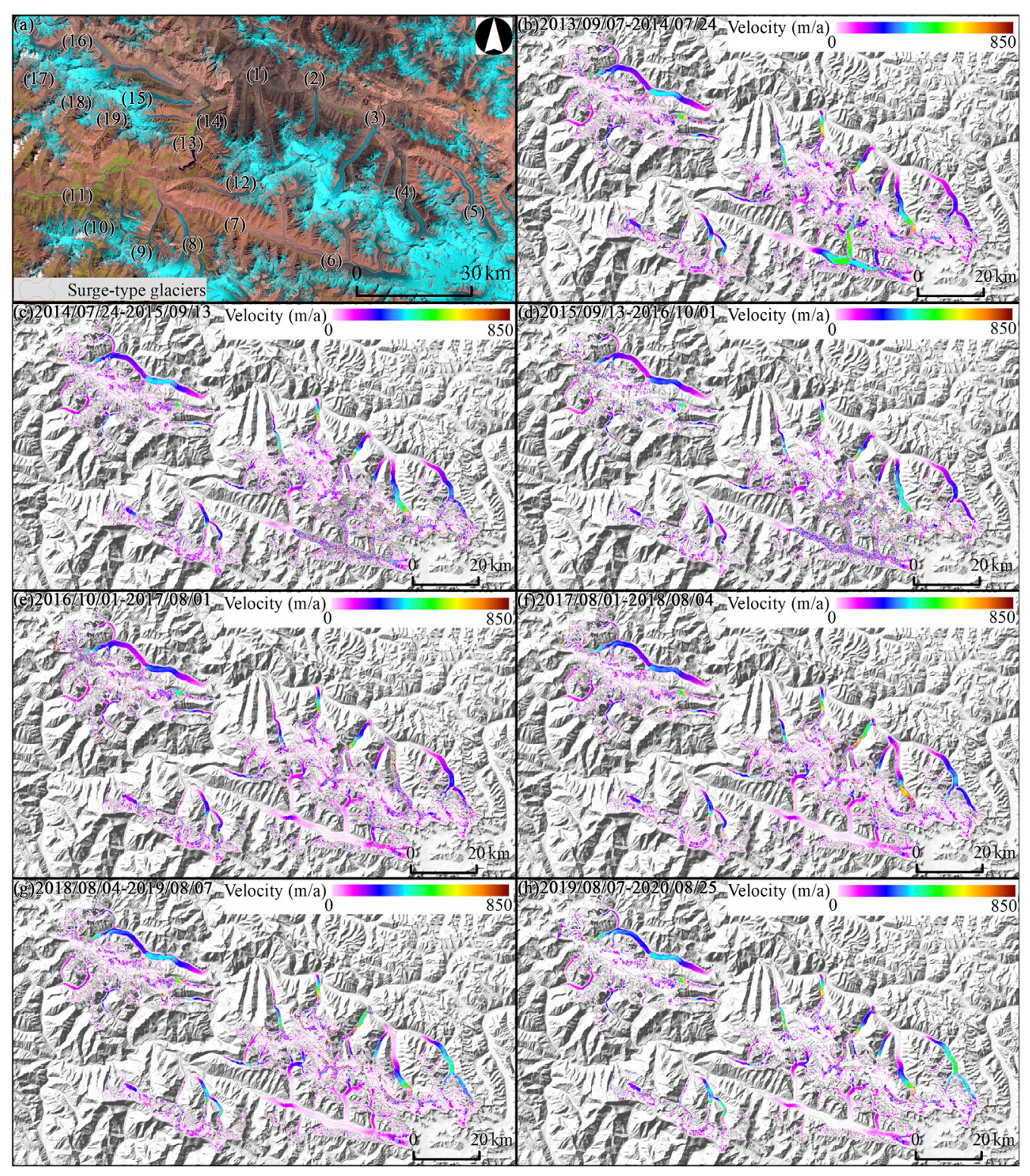

FIGURE 8| The change of annual surface velocities of surge-type glaciers in the Hunza valley. The glacier names in sub-panel (A) are as follows: (1) Momhil Glacier; (2) Malangutti Glacier; (3) Yazgil Glacier; (4) Khurdopin Glacier; (5) Virjerab Glacier; (6) Hispar Glacier; (7) Hopar Glacier; (8) Barpu Glacier; (9) Bualtar Glacier; (10) Minapin Glacier; (11) Pisan Glacier; (12) Gharesa Glacier; (13) Balt Bare Glacier; (14) Pasu Glacier; (15) Ghulkin Glacier; (16) Batura Glacier; (17) Baltar Glacier; (18) Muchuhar Glacier; and (19) Shispare Glacier. The results of sub-panel $\mathbf{( A )}-\mathbf{( H )}$ were obtained by Landsat OLI data. The date range represents the date of remote sensing image acquisition. The background is the hillshade from SRTM DEM.

GLOF is reduced; however, the middle and terminal regions of the Yagjil, Malangutti and Momhil Glaciers in the Shimshal Valley show signs of acceleration (Figures $\mathbf{8 B}-\mathbf{H}-\mathbf{H}$ ). In the future, the termini of these glaciers may block the Shimshal River and cause a GLOF. Although the terminus of the Shispare Glacier stopped advancing in 2019, it is still active (Figures $\mathbf{8 G}, \mathbf{H})$. The other glacier terminus is relatively stable (Figure 8).

As the climate warms and the melting of glaciers intensifies, the frequency of GFs, particularly GLOFs, will likely rise (Shugar et al., 2020; Bazai et al., 2020; Ding et al., 2020). At present, there are three glacial lakes along the $\mathrm{KKH}$, located at the termini of the Shispare, Khurdopin and Pasu Glaciers. Bhambri et al. (2020) calculated the water volume of the ice-dammed lake of the Shispare Glacier as being $1.66 \times 10^{7} \pm 6.4 \times 10^{6} \mathrm{~m}^{3}$, based on its area $\left(4.1 \times 10^{5} \pm 2 \times 10^{4} \mathrm{~m}^{2}\right)$ on May 31, 2019; the water depth was $134 \mathrm{~m}$. When it burst, the flood discharge flow reached $400 \pm 260 \mathrm{~m}^{3} \mathrm{~s}^{-1}$. This turbulent water eroded the edges of the $\mathrm{KKH}$, causing collapse and interrupting traffic (Bhambri et al., 2020). The formation and evolution of the icedammed lake at the terminus of the Khurdopin Glacier is closely related to the surge cycle of the glacier. Based on this surge cycle, we speculate that the evolution period of the ice-dammed lake is also 
about 20 years. Overall, as the global climate warms and the glaciers thin and produce more runoff, these lakes will fill faster and their ice dams will fail more readily. The frequency of newly forming Khurdopin ice-dammed lakes will gradually increase, as will their outburst frequency, during the glacier's surge process (Figure 2). Figure $7 \mathbf{F}$ shows changes in the area, water volume, water depth and peak discharge of the Khurdopin Glacier's ice-dammed lake during the glacier's last two surges. The lake had the largest area on May 30, 2000 , and its water volume, water depth and peak discharge were $6.7 \times 10^{7} \mathrm{~m}^{3}, 621 \mathrm{~m}$ and $2,289 \mathrm{~m}^{3} \mathrm{~s}^{-1}$, respectively (Huggel et al., 2002; Patel et al., 2017). In 2017, the size of the lake formed by the Khurdopin Glacier surge was smaller than that formed in 2000. The current lake area is $<0.4 \mathrm{~km}^{2}$, the average water depth does not exceed $160 \mathrm{~m}$, and the peak discharge is $301 \mathrm{~m}^{3} \mathrm{~s}^{-1}$. This indicates the characteristic of a shortened storage time for the lake. Therefore, we speculate that the ice-dammed lake of the Khurdopin Glacier will be characterized by small, high frequency outbursts with an obvious periodicity. Although it is somewhat distant from the $\mathrm{KKH}$, and its impact is relatively small, its threat to the village of Shimshal cannot be ignored (Figure 7C).

The glacial lake of the Pasu Glacier is the only morainedammed lake along the $\mathrm{KKH}$, and its outburst often occurs when an ice avalanche enters the lake, causing overtopping (Zhu et al., 2014). Based on the area of the lake on October 13, 2019, we used empirical formulae (Huggel et al., 2002) to infer that the water volume and peak discharge at the time of the outburst were $2.2 \times 10^{6} \mathrm{~m}^{3}$ and $84 \mathrm{~m}^{3} \mathrm{~s}^{-1}$, respectively. In short, as global climate change intensifies in the future, the glaciers along the $\mathrm{KKH}$ may advance due to GSs, resulting in new glacial lakes in places where glacial lakes have not previously been recorded (Figure 7A).

\section{CONCLUSION AND OUTLOOK}

With the intensification of global warming, the accelerated melting of glaciers and an increasing frequency of GSs will likely result in the frequent occurrence of glacier-related hazards along the $\mathrm{KKH}$, which will seriously threaten the safe operation of the highway and the lives and productivity of the residents living along the route. This has become a significant focus of academic attention. For this study, we combed through the literature and used remote-sensing interpretations and other means to determine that the glacier-related hazards along the $\mathrm{KKH}$ mainly relate to GSs and GLOFs. This study has highlighted the obvious characteristics of sudden, unpredictable and short hazard-causing processes, which are mainly distributed in the Hunza River Basin. In recent years, with the rise in global temperatures, the frequency of glacial hazards in this area has increased significantly.

The hydrology and temperature regimes of glaciers affect the development and evolution of those glaciers. Since the beginning of the 21st century, changes in the global climate have made it even more difficult for us to understand the mechanisms of, and therefore be able to predict, different glacial hazards. Based on our summarizing of previous studies, it became apparent that there are multiple trigger mechanisms for GSs along the $\mathrm{KKH}$. Also, these trigger mechanisms do not only relate to a glacier's attributes, but also involve external factors, such as increased short-term precipitation, ice-bed lithology, avalanches and earthquakes. However, there remain many unanswered questions. Is there a single explanation for all surges, or could multiple causes lead to similar oscillatory behaviors? Will the frequency and intensity of GSs increase in the future? Why do some glaciers oscillate between slow and fast flows, while the majority do not? Why are surge-type glaciers common in some regions, but not in others? (Herreid and Truffer, 2016; Benn et al., 2019). Answering these questions is challenging. It has been suggested that this clustering of surge-type glaciers might be related to particular climatic and geometric conditions, leading to periodic enthalpy imbalances, but the specific controls on surging remain poorly understood (Farinotti et al., 2020). In the future, based on strengthening our field observations, we should be able to explore the physical processes of GSs in greater detail; in particular, monitoring the evolution of the hydrology and the thermal state at the base of the glaciers. Although this is a daunting task, it would provide much-needed data for the optimization of model parameters, and thus an improvement in the accuracy of model simulations.

The outburst of the Pasu moraine-dammed lake along the $\mathrm{KKH}$ was primarily caused by an ice body falling into the lake. Modeling approaches can be adopted to reconstruct past GLOF of Pasu. Future scenario modeling will help to evaluate the potential future impact (Majeed et al., 2020; Schmidt et al., 2020). At present, the drainage process under the ice of the ice-dammed lake needs to be further observed and studied, especially concerning the mechanism behind the opening and closing of the drainage channel (Bazai et al., 2020). This will play a vital role in the prediction and early warning of GLOF hazards in the future and can be helpful for GLOF preparedness and mitigation (Majeed et al., 2020; Schmidt et al., 2020).

Against a background of continuous climate warming, we expect that the surge-type glaciers along the $\mathrm{KKH}$ will become more active in the future. Based on the surge cycles of these glaciers, we can infer the next surge start times, and can also estimate the water volumes and peak flood discharges of the lakes that may outburst, to provide early warnings and preventive measures protect the $\mathrm{KKH}$ and the villages along it from hazard. In summary, the Hunza River Basin is a high-risk area for glacierrelated hazards along the $\mathrm{KKH}$ and should be the focus of intensified research.

\section{AUTHOR CONTRIBUTIONS}

The study was designed by SL and YG. YG performed data analysis. YG and SL performed the analysis and drafted the first manuscript. KW, FX, MQ, and YZ discussed and improved the manuscript. All authors contributed to the article and approved the submitted version. 


\section{FUNDING}

This project has received funding from the National Natural Science Foundation of China (Grant Nos. 41761144075 and 41801031), the Second Tibetan Plateau Scientific Expedition and Research Program (STEP, Grant No. 2019QZKK0208), the Research Fund for Introducing Talents of Yunnan University (No. YJRC3201702), and the initiative for the promotion of Yunnan University in the development of a world-class university. YG was also supported by the Innovation Fund Designated for Graduate Students of Yunnan University (No. 2019226 and 2020Z47).

\section{REFERENCES}

Batura Glacier Investigation Group (1979). The Batura Glacier in the Karakoram mountains and its variations. Sci. Sin. 22, 958-974. doi:10.1360/za1978-8-6-657

Bazai, N. A., Cui, P., Carling, P. A., Wang, H., Hassan, J., Liu, D., et al. (2020). Increasing glacial lake outburst flood hazard in response to surge glaciers in the Karakoram. Earth Sci. Rev. 212, 103432. doi:10.1016/j.earscirev.2020.103432

Benn, D. I., Fowler, A. C., Hewitt, I., and Sevestre, H. (2019a). A general theory of glacier surges. J. Glaciol. 65, 701-716. doi:10.1017/jog.2019.62

Benn, D. I., Jones, R. L., Luckman, A., Fürst, J. J., Hewitt, I., and Sommer, C. (2019b). Mass and enthalpy budget evolution during the surge of a polythermal glacier: a test of theory. J. Glaciol. 65, 717-731. doi:10.1017/jog.2019.63

Bhambri, R., Hewitt, K., Kawishwar, P., and Pratap, B. (2017). Surge-type and surge-modified glaciers in the Karakoram. Sci. Rep. 7, 15391. doi:10.1038/ s41598-017-15473-8

Bhambri, R., Watson, C. S., Hewitt, K., Haritashya, U. K., Kargel, J. S., Pratap Shahi, A., et al. (2020). The hazardous 2017-2019 surge and river damming by Shispare Glacier, Karakoram. Sci. Rep. 10, 4685. doi:10.1038/s41598-02061277-8

Bhambri, R., Hewitt, K., Kawishwar, P., Kumar, A., Verma, A., Snehmani, et al. (2019). Ice-dams, outburst floods, and movement heterogeneity of glaciers, Karakoram. Global Planet. Change. 180, 100-116. doi:10.1016/j.gloplacha.2019. 05.004

Björnsson, H. (2017). Jökulhlaups in Iceland: prediction, characteristics and simulation. Ann. Glaciol. 16, 95-106. doi:10.1017/s0260305500004882

Bolch, T., Pieczonka, T., Mukherjee, K., and Shea, J. M. (2017). Brief communication: glaciers in the Hunza catchment (Karakoram) have been nearly in balance since the 1970s. Cryosphere. 11, 531-539. doi:10.5194/tc11-531-2017

Brun, F., Berthier, E., Wagnon, P., Kääb, A., and Treichler, D. (2017). A spatially resolved estimate of High Mountain Asia glacier mass balances, 2000-2016. Nat. Geosci. 10, 668-673. doi:10.1038/NGEO2999

Burgess, E. W., Forster, R. R., Larsen, C. F., and Braun, M. (20122008-2011). Surge dynamics on bering glacier, Alaska. Cryosphere. 6, 1251-1262. doi:10.5194/tc-61251-2012

Cai, X. X., Li, H., and Li, N. J. (1980). Causes and development trend of glacier debris flow in Balt Bare Gully. J. Glaciol. Geocryol. 1, 22-36.

Chen, C., Zhang, L. M., Xiao, T., and He, J. (2020). Barrier lake bursting and flood routing in the yarlung tsangpo grand canyon in october 2018. J. Hydrol. 583, 124603. doi:10.1016/j.jhydrol.2020.124603

Clarke, G. K. C., Collins, S. G., and Thompson, D. E. (1984). Flow, thermal structure, and subglacial conditions of a surge-type glacier. Can. J. Earth Sci. 21, 232-240. doi:10.1139/e84-024

Clarke, G. K. C., Nitsan, U., and Paterson, W. S. B. (1977). Strain heating and creep instability in glaciers and ice sheets. Rev. Geophys. 15, 235-247. doi:10.1029/ RG015i002p00235

Copland, L., Sylvestre, T., Bishop, M. P., Shroder, J. F., Seong, Y. B., Owen, L. A., et al. (2011). Expanded and recently increased glacier surging in the Karakoram. Arctic Antarct. Alpine Res. 43, 503-516. doi:10.1657/1938-4246-43.4.503

Dimri, A. P. (2004). Impact of horizontal model resolution and orography on the simulation of a western disturbance and its associated precipitation. Meteorol. Appl. 11, 115-127. doi:10.1017/S1350482704001227

\section{ACKNOWLEDGMENTS}

We thank the USGS and NASA for the freely available Landsat and ASTER imagery and ITS_LIVE data. We thank Luc Girod for providing the freely available MMASTER tool. We thank Muhammad Saifullah, Sidou Zhang, Xianhe Zhang, and Ying $\mathrm{Yi}$ at the Institute of International Rivers and EcoSecurity, Yunnan University, who involved in the conception of the manuscript. Finally, we thank the editor Dan H. Shugar and two reviewers for their constructive comments on the manuscript.

Ding, Y., Mu, C., Wu, T., Hu, G. D., Zou, D. Wang., Li, W., et al. (2020). Increasing cryospheric hazards in a warming climate. Earth Sci. Rev. doi:10.1016/j. earscirev.2020.103500

Dubey, S., and Goyal, M. K. (2020). Glacial lake outburst flood hazard, downstream impact, and risk over the Indian Himalayas. Water Resour. Res. 56, e2019WR026533. doi:10.1029/2019WR026533

Farinotti, D., Immerzeel, W. W., de Kok, R., Quincey, D. J., and Dehecq, A. (2020). Manifestations and mechanisms of the Karakoram glacier anomaly. Nat. Geosci. 13, 8-16. doi:10.1038/s41561-019-0513-5

Forsythe, N., Fowler, H. J., Li, X. F., Blenkinsop, S., and Pritchard, D. (2017). Karakoram temperature and glacial melt driven by regional atmospheric circulation variability. Nat. Clim. Change. 7, 664-670. doi:10.1038/NCLIMATE3361

Fowler, A. C., Murray, T., and Ng, F. S. L. (2001). Thermally controlled glacier surging. J. Glaciol. 47, 527-538. doi:10.3189/172756501781831792

Frappé, T.-P., and Clarke, G. K. C. (2007). Slow surge of trapridge glacier, yukon territory. Canada. J. Geophys. Res.: Earth Surface. 112 (F3). doi:10.1029/ 2006JF000607

Gao, H., Zou, X., Wu, J., Zhang, Y., Deng, X., Hussain, S., et al. (2020). Post-20 th century near-steady state of Batura Glacier: observational evidence of Karakoram Anomaly. Sci. Rep. 10, 1-10. doi:10.1038/s41598-020-57660-0

Gardner, A. S., Fahnestock, M. A., and Scambos, T. A. (2019). [update to time of data download]: ITS_LIVE regional glacier and ice sheet surface velocities. Colorado: Data archived at National Snow and Ice Data Center. doi:10. 5067/6II6VW8LLWJ7

Gilbert, A., Leinss, S., Kargel, J., Kääb, A., Gascoin, S., Leonard, G., et al. (2018). Mechanisms leading to the 2016 giant twin glacier collapses, Aru Range, Tibet. Cryosphere. 12, 2883-2900. doi:10.5194/tc-12-2883-2018

Girod, L., Nuth, C., Kääb, A., McNabb, R., and Galland, O. (2017). MMASTER: improved ASTER DEMs for elevation change monitoring. Rem. Sens. 9, 704 doi:10.3390/rs9070704

Goerlich, F., Bolch, T., and Paul, F. (2020). More dynamic than expected: an updated survey of surging glaciers in the Pamir. Earth Syst. Sci. Data. 12, 3161-3176. doi:10.5194/essd-12-3161-2020

Goudie, A., Jones, D. C., and Brunsden, D. (1984). Recent fluctuations in some glaciers of the western Karakoram mountains, Hunza, Pakistan, in The international Karakoram Project. International conference 411-455.

Haeberli, W. (1983). Frequency and characteristics of glacier floods in the Swiss alps. Ann. Glaciol. 4, 85-90. doi:10.3189/S0260305500005280

Harrison, S., Kargel, J. S., Huggel, C., Reynolds, J., Shugar, D. H., Betts, R. A., et al. (2018). Climate change and the global pattern of moraine-dammed glacial lake outburst floods. Cryosphere 12, 1195-1209. doi:10.5194/tc-12-1195-2018

Hayden, H. (1907). Notes on certain glaciers in northwest kashmir. Record Geol. Surv. India. 35, 127-137.

Herreid, S., and Truffer, M. (2016). Automated detection of unstable glacier flow and a spectrum of speedup behavior in the Alaska Range. J. Geophys. Res. Earth. Surf. 121 (1), 64-81. doi:10.1002/2015JF003502

Hewitt, K. (2005). .The Karakoram anomaly? Glacier expansion and the 'elevation effect,' Karakoram himalaya. Mt Res DevTKAGEA]2.02. 25, 332-340. doi:10. 1659/0276-4741(2005)025[0332

Hewitt, K. (2006). Glaciers of the Hunza basin and related features. Kreutzmann. H. $49-72$.

Hewitt, K. (2014). Glaciers of the Karakoram himalaya glacial environments. Processes, Hazards and Resources 1. 363. doi:10.1007/978-94-007-6311-1 
Hewitt, K., and Liu, J. (2010). Ice-dammed lakes and outburst floods, Karakoram Himalaya: historical perspectives on emerging threats. Phys. Geogr. 31, 528-551. doi:10.2747/0272-3646.31.6.528

Hewitt, K. (1982). Natural dams and outburst floods of the Karakoram Himalaya. IAHS. 138, 259-269.

Hu, W. T., Yao, T. D., Yu, W. S., Yang, W., and Gao, Y. (2018). Advances in the study of glacier avalanches in High Asia. J. Glaciol. Geocryol. 40, 1141-1152. doi:10.7522/j.issn.1000-0240.2018.0504

Huggel, C., Kääb, A., Haeberli, W., Teysseire, P., and Paul, F. (2002). Remote sensing based assessment of hazards from glacier lake outbursts: a case study in the Swiss Alps. Can. Geotech. J. 39, 316-330. doi:10.1139/t01-099

Iken, A. (1981). The effect of the subglacial water pressure on the sliding velocity of a glacier in an idealized numerical model. J. Glaciol. 27, 407-421.

Iken, A., and Bindschadler, R. A. (1986). Combined measurements of subglacial water pressure and surface velocity of Findelengletscher, Switzerland: conclusions about drainage system and sliding mechanism. J. Glaciol. 32, 101-119.

Iturrizaga, L. (1997). The valley of Shimshal-a geographical portrait of a remote high mountain settlement and its pastures with reference to environmental habitat conditions in the North-West Karakorum (Pakistan). Geojournal. 42 (23), 303-328. doi:10.1023/A:1006869406576

Jiskoot, H., Boyle, P., and Murray, T. (1998). The incidence of glacier surging in Svalbard: evidence from multivariate statistics. Comput. Geosci. 24, 387-399. doi:10.1016/S0098-3004(98)00033-8

Jones, D. K. C., Brunsden, D., and Goudie, A. S. (1983). A preliminary geomorphological assessment of part of the Karakoram Highway. Q. J. Eng. Geol. Hydrogeol. 16, 331-355. doi:10.1144/GSL.QJEG.1983.016.04.10

Kääb, A., Leinss, S., Gilbert, A., Buhler, Y., Gascoin, S., Evans, S. G., et al. (2018). Massive collapse of two glaciers in western Tibet in 2016 after surge-like instability. Nat. Geosci. 11, 114-120. doi:10.1038/s41561-017-0039-7

Kamb, B. (1987). Glacier surge mechanism based on linked cavity configuration of the basal water conduit system. J. Geophys. Res. 92, 9083-9100. doi:10.1029/ JB092iB09p09083

Kamb, B., Raymond, C. F., Harrison, W. D., Engelhardt, H., Echelmeyer, K. A., Humphrey, N., et al. (1985). glacier surge mechanism: 1982-1983 surge of variegated glacier, Alaska. Science 227, 469-479. doi:10.1126/science.227. 4686.469

Kotlyakov., V. M., Rototaeva, O. V., and Nosenko, G. A. (2004). The september 2002 kolka glacier catastrophe in north ossetia, Russian federation: evidence and analysis. Mt. Res. Dev. 24, 78-83. doi:10.1659/0276-4741(2004)024[0078: TSKGCI]2.0.CO;2

Kreutzmann, H. (1994). Habitat conditions and settlement processes in the Hindukush-Karakoram. Petermanns Geogr. Mittl. 138, 337-356.

Leprince, S., Barbot, S., Ayoub, F., and Avouac, J.-P. (2007). Automatic and precise orthorectification, coregistration, and subpixel correlation of satellite images, application to ground deformation measurements. IEEE Trans. Geosci. Rem. Sens. 45, 1529-1558. doi:10.1109/TGRS.2006.888937

Liao, L. P., Zhu, Y. Y., Yang, Z. Q., Wassem, M., Zou, S., Chen, J. D., et al. (2013a). Advance and retreat fluctuation of the ghulkin glacier along the karakoram highway over hundred years. J. Glaciol. Geocryol. 35, 1391-1399. doi:10.7522/j. issn.1000-0240.2013.0154

Liao, L. P., Zhu, Y. Y., Yang, Z. Q., Wassem, M., Zou, S., Chen, J. D., et al. (2013b). Debris flow hazards and prevention optimization along international Karakoram highway. Geol. Sci. Technol. Inf. 32, 168-174.

Lin, H., Li, G., Cuo, L., Hooper, A., and Ye, Q. (2017). A decreasing glacier mass balance gradient from the edge of the Upper Tarim Basin to the Karakoram during 2000-2014. Sci. Rep. 7, 6712. doi:10.1038/s41598-017-07133-8

Lingle, C. S., and Fatland, D. R. (2003). Does englacial water storage drive temperate glacier surges?. Ann. Glaciol. 36, 14-20. doi:10.3189/ 172756403781816464

Liu, C. Z., Lü, J. T., Tong, L. Q., Chen, H. Q., Liu, Q. Q., Xiao, R. H., et al. (2019). Research on glacial/rock fall-landslide-debris flows in sedongpu basin along yarlung zangbo River in Tibet. Chin. Geol. 46, 219-234. doi:10.12029/ gc20190201

Lv, M., Guo, H., Lu, X., Liu, G., Yan, S., Ruan, Z., et al. (2019). Characterizing the behaviour of surge-and non-surge-type glaciers in the Kingata Mountains, eastern Pamir, from 1999 to 2016. Cryosphere. 13, 219-236. doi:10.5194/tc-13219-2019
Majeed, U., Rashid, I., Sattar, A., Allen, S., Stoffel, M., Nüsser, M., et al. (2021). Recession of Gya Glacier and the 2014 glacial lake outburst flood in the TransHimalayan region of Ladakh, India. Sci. Total Environ. 756, 144008. doi:10. 1016/j.scitotenv.2020.144008

Mason, K. (1930). The glaciers of the Karakoram and neighbourhood. New Delhi: Geological Survey of India.

Meier, M. F., and Post, A. (1969). What are glacier surges?. Can. J. Earth Sci. 6 , 807-817. doi:10.1139/e69-081

Murray, T., Strozzi, T., Luckman, A., Jiskoot, H., and Christakos, P. (2003). Is there a single surge mechanism? Contrasts in dynamics between glacier surges in Svalbard and other regions. J. Geophys. Res. 108. doi:10.1029/2002JB001906

$\mathrm{Ng}$, F., and Björnsson, H. (2003). On the clague-mathews relation for Jökulhlaups. J. Glaciol. 49, 161-172. doi:10.3189/172756503781830836

Ng, F., and Liu, S. Y. (2009). Temporal dynamics of a Jökulhlaups system. J. Glaciol. 55, 651-665. doi:10.3189/002214309789470897

Norris, J., Carvalho, L. M. V., Jones, C., and Cannon, F. (2019). Deciphering the contrasting climatic trends between the central Himalaya and Karakoram with 36 years of WRF simulations. Clim. Dynam. 52, 159-180. doi:10.1007/s00382018-4133-3

Patel, L. K., Sharma, P., Laluraj, C. M., Thamban, M., Singh, A., and Ravindra, R. (2017). A geospatial analysis of samudra tapu and gepang gath glacial lakes in the chandra basin, western himalaya. Nat. Hazards. 86, 1275-1290. doi:10. 1007/s11069-017-2743-4

Qin, D. H. (2016). Dictionary of cryospheric science. Beijing: China Meteorological Press.

Quincey, D. J., Braun, M., Glasser, N. F., Bishop, M. P., Hewitt, K., and Luckman, A. (2011). Karakoram glacier surge dynamics. Geophys. Res. Lett. 38. doi:10.1029/ 2011GL049004

Quincey, D. J., Glasser, N. F., Cook, S. J., and Luckman, A. (2015). Heterogeneity in Karakoram glacier surges. Res. Earth. Surf. 120, 1288-1300. doi:10.1002/ 2015JF003515

Rashid, I., Abdullah, T., Glasser, N. F., Naz, H., and Romshoo, S. A. (2018). Surge of Hispar Glacier, Pakistan, between 2013 and 2017 detected from remote sensing observations. Geomorphology. 303, 410-416. doi:10.1016/j.geomorph.2017.12.018

Rashid, I., Majeed, U., Jan, A., and Glasser, N. F. (2020). The January 2018 to September 2019 surge of Shispare Glacier, Pakistan, detected from remote sensing observations. Geomorphology. 351, 106957. doi:10.1016/j.geomorph. 2019.106957

Raymond, C. F. (1987). How do glaciers surge? A review. J. Geophys. Res. 92, 9121-9134. doi:10.1029/JB092iB09p09121

Reynolds, J. M. (1992). "The identification and mitigation of glacier-related hazards: examples from the Cordillera Blanca, Peru," in Geohazards. Editors G. J. H. McCall, D. J. C. Laming, and S. C. Scott (London, UK: Chapman \& Hall), 143-157.

RGI Consortium (2017). Randolph Glacier inventory-A dataset of global glacier outlines: version 6.0: technical report, global Land ice measurements from Space. Colorado, USA: Digital Media. doi:10.7265/N5-RGI-60

Richardson, S. D., and Reynolds, J. M. (2000). An overview of glacial hazards in the Himalayas. Quat. Int. 65, 31-47. doi:10.1016/S1040-6182(99)00035-X

Roy, S. S., and Bhowmik, S. R. (2005). Analysis of thermodynamics of the atmosphere over northwest India during the passage of a western disturbance as revealed by model analysis field. Curr. Sci. 947-951 https:// www.jstor.org/stable/24110387.

Saifullah, M., Liu, S., Adnan, M., Ashraf, M., Zaman, M., Hashim, S., et al. (2020). Risks of glaciers lakes outburst flood along China Pakistan economic corridor. Glaciers and Polar Environ. IntechOpen. 1-17. doi:10.5772/intechopen.93459

Schmidt, S., Nüsser, M., Baghel, R., and Dame, J. (2020). Cryosphere hazards in Ladakh: the 2014 Gya glacial lake outburst flood and its implications for risk assessment. Nat. Hazards. 104, 2071-2095. doi:10.1007/s11069-020-04262-8

Sevestre, H., and Benn, D. I. (2015). Climatic and geometric controls on the global distribution of surge-type glaciers: implications for a unifying model of surging. J. Glaciol. 61, 646-662. doi:10.3189/2015JoG14J136

Shangguan, D., Liu, S., Ding, Y., Guo, W., Xu, B., Xu, J., et al. (2016). Characterizing the may 2015 karayaylak glacier surge in the eastern Pamir plateau using remote sensing. J. Glaciol. 62, 944-953. doi:10.1017/jog.2016.81

Shi, Y. F. (2003). An exploring innovative research case: recollection of the Batura Glacier expedition and research on restoring karakorum highway project. J. Glaciol. Geocryol. 25, 479-481. doi:10.3969/j.issn.1000-0240.2003.04.020 
Shi, Y. F., and Zhang, X. S. (1978). Historical variations in the advance and retreat of the Batura Glacier in the Karakoram mountains. Acta Geograph. Sin. 33, 27-40. doi:10.11821/xb197801002

Shugar, D. H., Burr, A., Haritashya, U. K., Kargel, J. S., Watson, C. S., Kennedy, M. C., et al. (2020). Rapid worldwide growth of glacial lakes since 1990. Nat. Clim. Change 10, 939-945. doi:10.1038/s41558-020-0855-4

Steiner, J. F., Kraaijenbrink, P. D. A., Jiduc, S. G., and Immerzeel, W. W. (2018). Brief communication: the Khurdopin glacier surge revisited-extreme flow velocities and formation of a dammed lake in 2017. Cryosphere 12, 95-101. doi:10.5194/tc-12-95-2018

Sun, M. P., Liu, S. Y., Yao, X. J., and Li, L. (2014). The cause and potential hazard of glacial lake outburst flood occurred on July 5, 2013 in Jiali County, Tibet. J. Glaciol. Geocryol. 36, 158-165. doi:10.7522/j.issn.1000-0240.2014.0020

Veh, G., Korup, O., and Walz, A. (2019). Hazard from Himalayan glacier lake outburst floods. PNA 117, 907-912. doi:10.1073/pnas.1914898117

Wang, L., Jiang, Z. L., Liu, S. Y., Shangguan, D. H., and Zhang, Y. (2019). Characteristic of glaciers movement along Karakoram highway. Remote Sensing Technology and Application. 34, 412-423. doi:10.11873/j.jssn.10040323.2019.2.0412

Wu, G. J., Yao, T. D., Li, S. H., Wang, W. C., Yu, W. S., Zhao, H. B., et al. (2019). Glacial hazards on Tibetan Plateau and surrounding alpines. BCAS. 34, 1285-1292. doi:10.16418/j.issn.1000-3045.2019.11.011

Yao, T. D., Yu, W. S., Wu, G. J., Xu, B. Q., Yang, W., Zhao, H. B., et al. (2019). Glacier anomalies and relevant disaster risks on the Tibetan Plateau and surroundings. Chin. Sci. Bull. 64, 2770-2782. doi:10.1360/tb-2019-0246

Yao, X., Iqbal, J., Li, L. J., and Zhou, Z. K. (2019). Characteristics of mountain glacier surge hazard: learning from a surge event in NE Pamir, China. J. Mt. Sci. 16, 1515-1533. doi:10.1007/s11629-018-5282-x
Yao, X. J., Liu, S. Y., Han, L., and Sun, M. P. (2017). Definition and classification systems of glacial lake for inventory and hazards study. Acta Geograph. Sin. 72, 1173-1183. doi:10.11821/dlxb201707004

Yasuda, T., and Furuya, M. (2015). Dynamics of surge-type glaciers in West Kunlun Shan, northwestern Tibet. J. Geophys. Res. Earth. Surf. 120, 2393-2405. doi:10.1002/2015jf003511

Zhang, D. F., and Gao, X. J. (2020). Climate change of the 21 st century over China from the ensemble of RegCM4 simulations. Chin. Sci. Bull. 65, 2516-2526. doi:10.1360/TB-2020-0231

Zhang, Z., Liu, S. Y., Wei, J. F., Jiang, Z. L., Guo, W. Q., and Xu, J. L. (2016). Monitoring recent surging of the Karayaylak Glacier in Pamir by remote sensing. J. Glaciol. Geocryol. 38, 11-20. doi:10.7522/j.isnn.1000-0240.2016.0002

Zhu, Y. Y., Yang, Z. Q., Zou, S., Wassem, M., and Ye, C. Y. (2014). Glacier geo-hazards along China-Pakistan international Karakoram highway. J. Highw. Transp. Res. Dev. 31, 51-59. doi:10.3969/j.isnn.1002-0268. 2014.11.009

Conflict of Interest: The authors declare that the research was conducted in the absence of any commercial or financial relationships that could be construed as a potential conflict of interest.

Copyright (c) 2021 Gao, Liu, Qi, Xie, Wu and Zhu. This is an open-access article distributed under the terms of the Creative Commons Attribution License (CC BY). The use, distribution or reproduction in other forums is permitted, provided the original author(s) and the copyright owner(s) are credited and that the original publication in this journal is cited, in accordance with accepted academic practice. No use, distribution or reproduction is permitted which does not comply with these terms. 